\title{
3-Hydroxysteroid Dehydrogenase Inhibitor
}

National Cancer Institute

\section{Source}

National Cancer Institute. 3-Hydroxysteroid Dehydrogenase Inhibitor. NCI Thesaurus.

Code C2184.

A hydroxysteroid dehydrogenase inhibitor that is specific for 3-hydroxysteroid dehydrogenase. 